Relations industrielles

Industrial Relations

\title{
Interactions between Dispatchers and Truck Drivers in a High Turnover Context
}

Les relations entre les répartiteurs et les camionneurs en contexte de roulement élevé de main-d'oeuvre

\section{Las relaciones entre los repartidores y los camioneros en contexto de rotación elevada de mano de obra}

\author{
Pierre-Sébastien Fournier, Sophie Lamontagne et Julie Gagnon
}

Volume 67, numéro 2, printemps 2012

URI : https://id.erudit.org/iderudit/1009087ar

DOI : https://doi.org/10.7202/1009087ar

Aller au sommaire du numéro

\section{Éditeur(s)}

Département des relations industrielles de l’Université Laval

ISSN

0034-379X (imprimé)

1703-8138 (numérique)

Découvrir la revue

Citer cet article

Fournier, P.-S., Lamontagne, S. \& Gagnon, J. (2012). Interactions between Dispatchers and Truck Drivers in a High Turnover Context. Relations industrielles / Industrial Relations, 67(2), 263-282.

https://doi.org/10.7202/1009087ar

\section{Résumé de l'article}

Les problèmes de rétention de main-d'oeuvre qualifiée se dessinent depuis les années 80 dans l'industrie du transport routier des marchandises en Amérique du Nord. Ces problèmes entraîneraient des conséquences économiques et sociales importantes. Par exemple, une augmentation du taux de roulement serait associée à une augmentation des accidents. La littérature scientifique a clairement établi un lien entre le rôle du répartiteur et le roulement des camionneurs. Si ce lien est bien connu, on en sait peu sur la dynamique de cette relation dans la réalité quotidienne du travail. L'objectif de cet article consiste à documenter le contexte dynamique qui structure la relation entre les répartiteurs et les camionneurs pour faire face aux problèmes de roulement de main-d'oeuvre. Une démarche qualitative visant à documenter la réalité quotidienne des acteurs a été utilisée. Elle repose sur 17 entrevues individuelles et trois entretiens collectifs réalisés auprès de représentants patronaux, de répartiteurs, de représentants syndicaux et de camionneurs oeuvrant dans 11 organisations distinctes. Les résultats présentent des caractéristiques de la dynamique du travail au quotidien : l'importance de la relation dans l'efficacité et la qualité des opérations, la prédominance de la satisfaction du client dans la relation, la relation d'interdépendance entre le répartiteur et le camionneur et, finalement, l'écoute et le respect dans les activités de transport. De façon plus spécifique, l'étude montre un contexte d'interaction caractérisé par de fortes contraintes de travail où la pression productive amène souvent les acteurs à prioriser les préoccupations opérationnelles aux dépens des aspects relationnels. De plus, elle montre une relation de donnant donnant entre les acteurs où les bonnes relations, le respect et l'écoute constituent des conditions importantes pour la réalisation efficace et satisfaisante du travail. Ces résultats confirment plusieurs constats d'études précédentes et apportent de nouveaux éclairages dans la compréhension de la relation entre ces acteurs.
Tous droits réservés @ Département des relations industrielles de l’Université Laval, 2012
Ce document est protégé par la loi sur le droit d'auteur. L'utilisation des services d'Érudit (y compris la reproduction) est assujettie à sa politique d'utilisation que vous pouvez consulter en ligne.

https://apropos.erudit.org/fr/usagers/politique-dutilisation/ 


\title{
Interactions between Dispatchers and Truck Drivers in a High Turnover Context
}

\author{
Pierre-Sébastien Fournier, Sophie Lamontagne and \\ Julie Gagnon
}

This article focuses on interactions between dispatchers and drivers in addressing issues related to high turnover in the trucking industry. The study uses a qualitative approach, based on 17 individual interviews and three group discussions with dispatchers, truck drivers and labour and management representatives from 11 different Quebec-based organizations. The results reveal four key characteristics influencing the day-to-day dynamics of trucking operations: 1) the importance of dispatcher-driver interactions in efficient and quality work operations; 2 ) the precedence of customer satisfaction in these interactions; 3) the interdependent nature of the dispatcher-driver relationship; and 4) the role of listening and mutual respect. These findings provide new insight into understanding this relationship that is critical to driver retention.

KEYWORDS: dispatchers, truck drivers, retention, turnover

\section{The Issue}

Given the revenues it generates and the fluidity it brings to trade, the trucking industry is an essential link in the economic chain (Gouvernement du Québec, 1999). Yet issues related to the retention of a skilled workforce have been emerging since the end of the 1980s and pose a major challenge to the growth and prosperity of carriers (Price-Waterhouse, 1990). Along with the cost of fuel and competition over rates, the challenge of retaining qualified drivers is one of the top three threats to the long-term survival of the trucking business (Camo-route, 2005). The urgent need to understand the phenomenon of driver turnover and implement effective strategies to address it makes this all the more relevant.

The effects of high driver turnover are numerous, and stand to jeopardize not only the industry's bottom line, but employee well-being and public safety as

Pierre-Sébastien Fournier, Professor, Department of Management, Research Chair in Occupational Health and Safety Management, Université Laval, Québec (pierre-sebastien.fournier@fsa.ulaval.ca).

Sophie Lamontagne, Research Professional, Research Chair in Occupational Health and Safety Management, Université Laval, Québec.

Julie Gagnon, Research Professional, Research Chair in Occupational Health and Safety Management, Université Laval, Québec. 
well. Indeed, productivity losses can be great and replacement costs high-up to approximately $200 \%$ of an employee's salary (Griffeth and Hom, 2001). Beyond the considerable financial cost, this turnover also has a significant impact on a human scale: the remaining employees typically must perform additional tasks to keep the company operating efficiently, which in turn may result in an increase in workload and a drop in performance (Mobley, 1982). High driver turnover could also lead to more frequent road accidents (Corsi and Fanara, 1988; Staplin and Gish, 2005), as the first few months in a new job is a high-risk period for all drivers-regardless of age — with a greater likelihood of accidents (Breslin and Smith, 2006). An increase in the turnover rate would thus mean a higher number of new truck drivers and even more at-risk situations, both for the drivers themselves and others on the road. Lastly, within the context of an aging workforce, high driver turnover becomes a critical issue in managing not only employee succession plans, but the efficiency and safety of haulage operations as well.

Over the past two decades, a large number of studies on the phenomenon of voluntary turnover among truck drivers have brought to light several determining factors, beginning with age, seniority, education and compensation (Beilock and Capelle, 1990). Other studies identified management practices, notably salary and benefits (Stephenson and Fox, 1996; Min and Lambert, 2002), recognition and job value (Stephenson and Fox, 1996), restricted latitude in decision making (De Croon et al., 2004), as well as electronic surveillance and monitoring policies (Shaw et al., 1998). Moreover, the very nature of haulage operations itself (i.e. type of freight, distance travelled, rest time, waiting time, weekend shifts, mileage rates) is also seen as an important determinant (Suzuki, Crum and Pautsch, 2009). Lastly, many studies have clearly identified the role of the dispatcher as a key factor in driver turnover (Richard, LeMay and Taylor, 1995; Stephenson and Fox, 1996; Keller and Ozment, 1999a, 1999b; Keller, 2002; Min and Lambert, 2002; Morrow et al., 2005; Paillé, Fournier and Lamontagne, 2011). This body of research overwhelmingly suggests that the dispatcher's sensitivity and response to drivers' concerns are closely linked to voluntary turnover among the latter. More specifically, this sensitivity encompasses an awareness of: 1) drivers' concerns; 2) the dispatcher's own role in addressing driver turnover and 3) drivers' feedback to the dispatcher (Keller and Ozment, 1999b). It follows, then, that dispatchers with good listening skills who effectively address their drivers' concerns could help reduce driver turnover more than those who fail to recognize the importance of empathic communication and maintaining a strong relationship of trust with their drivers.

These studies, however, are largely based on questionnaires designed to measure respondent attitudes and perceptions, and, as such, provide very little 
insight into the operational aspects of the work itself (Suzuki, Crum and Pautsch, 2009). As a result, although the dispatcher's role in driver turnover seems to be rather well-defined in the literature, the actual interactions underpinning the dispatcher-driver relationship in a work environment remain largely unexplored. More in-depth knowledge of these dynamic interactions in an organizational context could bolster understanding of the issue and pave the way for successful driver retention strategies. The objective of the present article is therefore to document, starting from a qualitative approach, the dynamic environment shaping interactions between dispatchers and truck drivers in addressing issues related to high turnover.

\section{Theoretical Framework}

Current research on the phenomenon of high turnover has identified an evolving and sequential process in job dissatisfaction which can often result in a breakdown in the employee-organization relationship. This typically occurs prior to the former's decision to leave the latter (Vandenberghe, 2004). This mental and cognitive progression takes place in four key stages: 1) the thought of quitting; 2) the intention of finding an alternative; 3) the intention of quitting; and 4) the act of quitting (Mobley, 1982). Of these, the intention of quitting would appear to be the best predictor of actual voluntary turnover (Mobley, 1982; Tett and Meyer, 1993; Hom and Griffeth, 1995). Defined as a conscious and deliberate desire by an employee to leave an organization (Mobley, 1982), this "intention" could be ascribed to the fact that prior to engaging in any behaviour, individuals tend to consider available information and evaluate the consequences of their actions (Ajzen and Fishbein, 1980). In other words, although intention may not always lead to action, more often than not individuals are likely to act upon their intentions. Similarly, there appears to be a correlation between an individual's intention to quit and employee turnover rates (Griffeth, Hom and Gaertner, 2000): The greater the intention to quit, the greater the likelihood of the employee actually leaving the employer. Of course, the employer can step in during this process to address any concerns the employee may have and, hopefully, play a part in the retention of its skilled workforce (Vandenberg and Nelson, 1999).

An important factor in the breakdown of the employee-organization relationship is the quality of the interactions between employees and their immediate supervisors (Stinglhamber and Vandenberghe, 2003; Vandenberghe, 2004). While their main role is that of a company representative, supervisors can also become custodians of employee concerns, expectations and frustrations (Eisenberger et al., 2002). Indeed, to a great extent employees often perceive their supervisor's positive or negative attitude towards them as a reflection of the company's organizational support (Rhoades and Eisenberger, 2002). Conflict 
with an immediate supervisor can therefore constitute a major reason for quitting (Houkes et al., 2003) and can be associated with a perception of unfairness (DeConinck and Bachmann, 2005) that can trigger the job satisfaction process. Consequently, there appears to be a positive relationship between perceived supervisor support and employee job satisfaction (Griffeth and Hom, 2001; Price, 2001), with some supervisory practices directly affecting the latter (Price, 2001). Employee job satisfaction is the result of a cognitive process where employees measure their current job situation against a frame of reference (Smith, Kendall and Hulin, 1969): They first contrast their present job with expectations established before hiring, then gauge to what degree these expectations match the perceived reality before deciding whether they are satisfied with their current position. Dissatisfied employees are more likely to quit than remain with their employers (Hirschman, 1970).

Moreover, the nature of employee relationships with immediate supervisors and co-workers presupposes the concept of affective commitment. This commitment refers to an emotional attachment to the organization, supervisors and co-workers, manifested in feelings of loyalty and an obligation to stay with the organization and contribute to it (Meyer, Allen and Smith, 1993; Meyer and Herscovitch, 2001). When employees are strongly attached on an affective level, they are more willing to invest effort in the effective operation of their organization and wish to remain a part of it (Tett and Meyer, 1993).

Consequently, the nature of the dispatcher-driver relationship can have a significant impact on both job satisfaction and affective commitment, and ultimately influence drivers' intentions to quit. Greater understanding of the dynamic interactions between these players from the outset could thus expand knowledge of the phenomenon of voluntary driver turnover in the trucking industry.

\section{The Process of Experience In the Dispatcher-Driver Relationship}

Understanding the dynamics of the dispatcher-driver relationship in a dayto-day work environment also presupposes considering the individual's experience, which is continually transformed through his or her interactions with the environment (Natanson, 1962; Varela, 1989). This experience is not static, but rather a life-long process of transformation of the individual's culture (Dewey, 1963). The process attaches primary importance to past experience and interactions with action situations (Figure 1). Each action situation (and its interaction) would then be the result of an internal historical construction where the individual provides a sense to the situation at hand, starting from his or her own experience (Vygotski, 1997). To grasp the dynamics and the meaning attributed to these situations, they must be examined from the perspective of the players involved and their experience in the workplace (Fournier, 2003). 


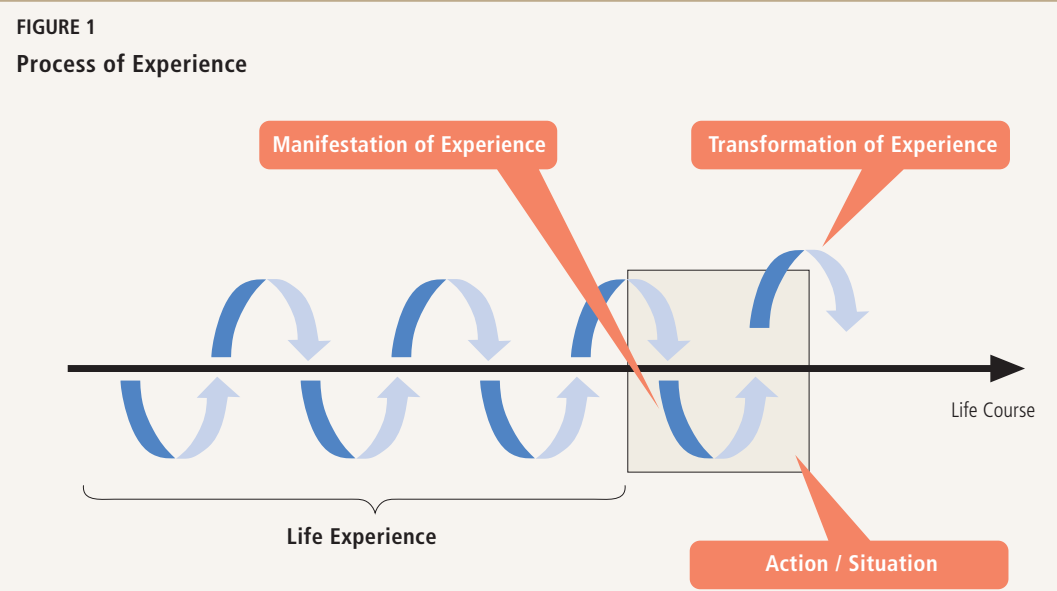

From Fournier (2003)

The above definition of the individual's experience closely aligns with our selected reference model (Figure 2), which is based on an analysis of activity (Guérin et al., 2006). This model places action situations (and their interactions) at the centre of this analysis: the context where work-related and organizational pressures (e.g. performance objectives, work allocation procedures, available resources) and individual resources (e.g. past experience, state of fatigue) are transformed (de Montmollin, 1986; Lamonde and Montreuil, 1995). Similarly, these situations impact both the individual (e.g. job satisfaction, affective commitment, health) and the organization (quality, turnover) (Lamonde and Montreuil, 1995).

\section{FIGURE 2}

Reference Model

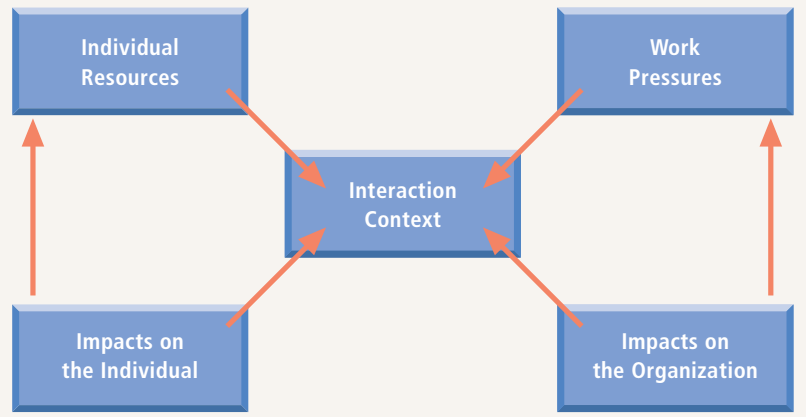




\section{Methodology}

Consideration of our issue concerned the following investigative question: Which characteristics of the dispatcher-driver relationship in the dynamic work environment of the trucking industry have a positive or negative effect on job satisfaction, affective commitment and ultimately on a driver's intention to quit? To thoroughly grasp the scope of this relationship, a case study was conducted in which the issue of driver turnover was further examined and analyzed from the players' perspective (Maertz, 2004). In fact, to fully understand its complexities, it proved prudent to expand the sources of information and include key stakeholders in order to identify key issues as well as the social context. To properly document the issues, ensure a degree of impartiality in data collection, and optimize the generalizability of data, 11 different Quebec-based organizations that work for hire in the trucking industry were selected. A mixed-method study was adopted, including a survey based on semi-structured individual interviews and group discussions, a review of the literature and field notes.

First, 17 semi-structured individual interviews were conducted with drivers (8), management representatives (4), dispatchers (3) and labour representatives (2). A purposive sampling method was employed based on the criteria of age, position and work experience. The sample comprised 15 males and 2 females aged 26 to 45 with an average of 12 years' experience in the trucking industry (range $=6$ months at the age of 40 ) and 5 years' seniority with their current employers (range $=3$ months at the age of 18). The gap in seniority between that with their current employer and that within the industry enabled the research team to ensure the sample cohort had previously experienced voluntary job change. The principle of theoretical saturation was applied to cap the number of participants (Mucchielli, 1991); this explains the small number of interviews conducted. Averaging 62 minutes in duration, these interviews were structured around four main areas of discussion: the participant's experience in and views on the issue of turnover, the range of work-related pressures experienced by truck drivers; current organizational strategies addressing these issues; and promising innovative solutions at the local and/or industry-wide levels.

Second, three group discussions of an average three-hour duration were conducted (Kvale, 1996) comprising dispatchers (4), drivers (4) and labour representatives (3). Participants in these discussions were different than those in the individual interviews. Purposive sampling was also used to select these participants, and the principle of theoretical saturation was observed as well. The objective of these semi-structured discussions was to validate and expand on the initial results obtained from the individual interviews and thus optimize generalizability of the data. 
Third, data coding was undertaken, starting with verbatim transcriptions of the individual interviews and group discussions, as well as field notes. A preliminary analytical matrix was created using both the information collected (an open and inductive analysis of data generalization and abstraction) and literature (an evaluation and translation of available study indicators to validate the theories referenced in our study). This was controlled and adjusted throughout the coding process. The participants' main views on dispatcher-driver interactions were then coded using textual information (verbatim phrases) with specific meaning as the units of analysis. These met the criteria of exhaustiveness, exclusivity, objectivity and relevance to the study.

Fourth, an analysis of the empirical data was carried out in four stages: 1) analytical (examining categories and sub-categories in-depth); 2) synthetic (abstracting categories and central ideas); 3) explanatory (identifying possible factors influencing voluntary driver turnover and links between categories and sub-categories); and 4) validation (triangulating data against a cross-perspective of the participants' views and placing convergences and divergences into perspective) (Ezzy, 2003). Lastly, a hybrid approach was adopted to merge the inductive and deductive methods (Denzin and Lincoln, 2005). This made it possible to formulate a general yet exhaustive interpretation of the characteristics found in the dynamics of dispatcher-driver interactions.

\section{Results}

The results of our study reveal the work pressures inherent in trucking operations and the industry itself that shape day-to-day interactions between dispatchers and drivers. Our analysis of these pressures rests on a cross-perspective of the different stakeholders in this relationship: dispatchers, drivers, and labour and management representatives. The presentation of our results is structured around four key characteristics influencing the day-to-day dynamics of trucking operations: 1) the importance of dispatcher-driver interactions in efficient and quality work operations; 2) the precedence of customer satisfaction in these interactions; 3) the interdependent nature of the dispatcher-driver relationship; and 4 ) the role of listening and mutual respect.

\section{Respective Duties of Dispatchers and Truck Drivers}

In all the carriers that participated in our study, both dispatchers and drivers reported to an Operations Manager. This means that in strict hierarchical terms, the former is not the latter's immediate supervisor. Yet on an operational level, the dispatcher's responsibilities and daily duties include a certain amount of driver supervision: assigning pickups and deliveries, coordinating the smooth running of operations and troubleshooting any logistical issues that may arise between 
the customer, the driver, the shipper and the freight itself. When an issue persists or needs to be escalated, it is handled by the Operations Manager.

The dispatcher's job is to meet the haulage needs of customers. These can be spread across a wide territory and often must be met under tight schedules (e.g. a customer contacts dispatch to request pickup of a load during business hours for next-day delivery to a given location). In simple terms, the dispatcher's task is to assign a driver and truck to haul the freight. Yet, in addition to ensuring full customer satisfaction, coordinating haulage is also equally driven by optimizing cost. To do so, the dispatcher must consider the physical location of trucks, the availability of drivers in relation to other ongoing operations, the number of driving hours, the customer's business hours, available space in the truck, as well as many other logistics. With frequent new requests from customers and/ or unforeseen events (e.g. accidents or vehicle breakdowns), dispatchers must reassign their fleet on the fly to optimize operations. Throughout this dynamic juggling of haulage, dispatchers are in constant contact with their drivers. This communication may take place via e-mail, phone calls and/or in person, allowing dispatchers to assign new tasks, clarify details and monitor the operations in progress.

For their part, drivers must safely deliver the freight on time, in good order and at the right location, while observing applicable laws and regulations. The driver's task, then, is to ensure the moving and handling of freight while respecting the specifics of each work order. To do so, drivers must fully leverage the use of their vehicles under a given set of conditions. In carrying out their duties, drivers similarly encounter unforeseen events that can impact their work: delays at the shipper's loading dock, traffic jams, customs holds, vehicle breakdowns, etc. Faced with such situations, drivers must often adjust and rearrange their workload in real time. Communication with the dispatcher thus becomes an indispensable tool in solving problems and delivering the freight as specified. Through interaction with their dispatcher, drivers are able to better understand customer requests (as well as those of the dispatcher), get support in handling crises, monitor the progress of any ongoing situations, and clarify the work assigned.

\section{The Importance of Dispatcher-Driver Interactions in Efficient and Quality Work Operations}

The very nature of trucking operations demands that drivers be on the road alone at all hours of the day and night, with very little time spent at their employer's premises. Communicating and interacting with the carrier is customarily done through the dispatcher, via e-mail or telephone. In this respect, all stakeholders acknowledge the pivotal role of the dispatcher in developing and maintaining successful relationships with drivers: 
... a really big role, that of the dispatcher. Otherwise you have a big problem with employee turnover. (Driver)

The ones who stay, in my opinion, stay because they get along really well with their dispatcher. The relationship with the dispatcher is very important-it's the person the driver talks to every day. (Manager)

When a driver gets along with his dispatcher, he's not going to go somewhere else and start over with someone he doesn't know. The one who doesn't like his dispatcher, on the other hand-he's going to look for a job somewhere else. (Dispatcher)

Acting as a bridge between the driver, the carrier, the shipper and the customer, the dispatcher is the one who ensures cohesion throughout the transportation chain. As such, dispatchers not only represent the carrier's interests, but also coordinate their drivers' runs with an eye on operations, and to do so must build a relationship of listening and trust. Depending on the balance achieved between these responsibilities, this relationship can either aid or hinder the course of operations. Open and transparent communication is therefore a must. Indeed, drivers expect their dispatcher to share and convey all relevant information needed to fully carry out their work:

You've got to stop always saying to drivers that you're stuck, because sooner or later they're going to start wondering if you're telling the truth or you're simply not good at planning your stuff. At some point it'll come back to bite you. You should always try to be fair, it's the only way you can hold on to your drivers. (Dispatcher)

As for drivers, they directly interact with several stakeholders (customers, dispatchers and co-workers) as they carry out their duties and seek to establish a good relationship with each. When a problem arises - a wrong delivery, for exampledrivers are typically at the receiving end of the customer's frustration, even when the problem is beyond their control. When drivers feel a lack of support in resolving problems, any trust they may have forged with the carrier can often be broken. A trucking manager aptly summarizes the role of communication in this regard:

The funny thing about trucking is that the most important thing is not the truck, but the communication, because this is, after all, a service - a service that needs to talk to the customer, talk to the salesperson, talk to the dispatcher, talk to the driver, talk to the customer. That's five simple steps, but it's like playing telephone! It's not easy to get a message through these five parties without something going wrong. If there's a break in communication, it's the driver who's going to get it, because he's the one at the end of the line!

Trucking industry stakeholders readily agree on the importance of the dispatcher's role in influencing driver satisfaction, and this awareness is expressed primarily in terms of communication. 


\section{The Precedence of Customer Satisfaction in Dispatcher-Driver Interactions}

The trucking industry is a highly competitive business characterized by strong competition and slim profit margins, where customer loyalty often hinges on the quality of service. A carrier must therefore do everything it can to accommodate the specific demands of the customer or risk losing the account. In such a context, dispatchers often find themselves under tremendous pressure to schedule and reschedule haulage operations on the fly to meet their customers' needs, thus impacting the workload of their drivers. This tenuous balance between ensuring customer satisfaction and driver well-being is a challenge in and of itself:

Those of us in Operations, we're always caught between a rock and a hard place, with customers at one end and drivers at the other ... We're always trying to arrange things so that customers can get their freight on time and drivers can deliver while complying with standards and regulations and their own pace. (Dispatcher)

When work volumes are high, dispatchers tend to focus on the operations at hand and proportionately decrease their availability to drivers. Consequently, the relational aspects of listening and support are deprioritized—by being less available to their drivers, dispatchers are able to fully devote their attention to the immediate demands of production. Used in moderation, this strategy can be effective. However, where it becomes common practice, it can lead to a perception of unfairness that may be harmful to the dispatcher-driver relationship:

Being a dispatcher is understanding the flow, knowing guys, and being able to put yourself in their shoes. Of course, when we have a lot of work I often say "On Thursdays and Fridays the shrink is OUT ..." We have a lot of work on those days; deliveries need to get done. Some customers might want their goods before the weekend. (Dispatcher)

\section{The Interdependent Nature of the Dispatcher-Driver Relationship}

Executing haulage operations is heavily dependent on close teamwork between drivers and dispatchers. Drivers rely on dispatchers not only to schedule good "runs," but also to be there for them to help solve problems as they occur, be they customer-related (special requests, delivery procedures, etc.) or difficulties encountered along the route. In turn, dispatchers rely on drivers to be their eyes and ears on the road. Indeed, drivers provide feedback on deliveries and customer expectations that can be very useful for dispatchers in effectively coordinating haulage operations; in other words, a reciprocal, "give-and-take" relationship where drivers assist dispatchers and the latter show some flexibility in scheduling the former's workload:

I have to say, I always get what I want from a driver; it's rare that they turn me down. When a guy asks me for something, I'm flexible-if he's tired, I don't push him to 
finish. But when I'm stuck, and we have a lot of work to do and a lot of customers to serve-when it's my turn to ask for help, I get it. (Dispatcher)

The balance in this interdependent relationship is a delicate one and requires ongoing effort on the part of both parties to maintain. Any breach can have a significant impact on trust. For example, a driver temporarily assigned to dispatch overhears a situation where a fellow driver needs to pick up a load in the Midwestern United States. Noticing that address information is incomplete, the driver contacts the dispatcher, who refuses to help, claiming that he should be able to handle it all by himself:

You don't do that to someone who's all alone halfway around the world. You have an obligation to help; it's a question of trust. You need to know that if you're stuck there's somebody out there to help you ... As soon as I get a chance I'm going to change companies. (Driver)

\section{The Role of Listening and Mutual Respect}

The nature of their trade is such that truck drivers often spend a great deal of time alone. Consequently, the quality of interactions with their dispatcher takes on an even greater importance. After long stretches on the road, a relatively minor issue may turn into a crisis. Indeed, in day-to-day interactions, how a dispatcher addresses a driver and conveys a message can significantly influence their relationship:

... you need to have good communication and a dispatcher who can listen. Communication is not simply saying "That's how it's done here." You can always find a way to say something. (Manager)

Approach is so important. It's $60 \%$ of your request to the driver. (Dispatcher)

[This morning] we had three guys from Quebec City asleep in the yard [in their trucks] who didn't want to go get loads [pick up freight at a customer]. I said OK, we're gonna let them sleep and when they wake up they'll come and see me. When they did, it went like this: "How's it going?," I shook their hands, I listened to them, we talked. You should never think you're better than they are. (Dispatcher)

Faced with mounting work pressures, dispatchers generally bear the brunt of everyone's frustration. To be able to provide technical and moral support, they must listen to drivers and be sympathetic to their various personal and work problems:

A good dispatcher is also a good therapist, one who can listen to drivers and figure out what's going on... Some will never tell you a thing and one day they're gone. You've always got to be one step ahead... (Dispatcher)

Conversely, drivers who feel their voice is seldom heard experience work pressures differently, and sometimes perceive dispatchers' demands to be un- 
reasonable and devoid of any compassion. This inevitably impacts driver job satisfaction:

... in big companies people are treated like numbers instead of people... I never felt I counted as a person with them [dispatchers]; I was nothing more than a work tool... (Driver)

You know the most important thing that makes people stay with a company more than anything else? It's the relationships, it's the respect. I'd say $80 \%$ of people switch jobs because of this. (Labour Representative)

Given these characteristics of dispatcher-driver interactions, it is evident that the work environment in the trucking industry appears to be a major determining influence on their relationship. It is also clear that the higher the work volumes, the greater the strain on this relationship, and the greater likelihood of it deteriorating. Driver satisfaction and commitment thus seem to hinge on the ability of dispatchers and drivers to bond on a human scale through listening and mutual respect. Consequently, addressing the issue of the intention to quit among drivers means maintaining the quality and health of this relationship in spite of inherent work pressures.

\section{Discussion and Conclusion}

The issue of qualified driver retention remains a major challenge for the trucking industry. With an economic turnaround in the transportation sector and mass retirements from the workforce, the ability of a carrier to retain its drivers, both young and old, could pose a serious threat to its survival and long-term prosperity. This issue impacts both the availability of a labour pool and the development of qualified employees (Foucher and Gosselin, 2004), two necessary requirements for managing employee succession in organizations. Carriers that can retain a stable workforce greatly benefit from employee loyalty, experience and expertise. Conversely, those unable to do so may find it difficult to transition a new generation of drivers and still meet the criteria of quality service, efficiency and occupational safety. Yet, before implementing any successful retention strategies, it is vital to understand the factors influencing voluntary driver turnover. Our review of the literature has identified dispatcher-driver interactions as one of the key factors in this phenomenon. Indeed, dispatchers are seen as a bridge between the carrier and its employees, conveying company values and information, as well as a custodian of employee expectations, responsible for allocating material resources and providing emotional support critical to building employee loyalty (Stinglhamber and Vandenberghe, 2003). However, beyond these roles and responsibilities, very little is known about the dynamics that underpin their day-to-day interactions with drivers. 
A cross-perspective on the views of the various stakeholders made it possible to isolate factors influencing the dispatcher-driver relationship and, in turn, driver job satisfaction and affective commitment. This enabled us to identify four key characteristics influencing the day-to-day dynamics of trucking operations: 1) the importance of dispatcher-driver interactions in efficient and quality work operations; 2) the precedence of customer satisfaction in these interactions; 3 ) the interdependent nature of the dispatcher-driver relationship; and lastly, 4) the role of listening and mutual respect. These characteristics contributed to a better understanding of the day-to-day work dynamics between dispatchers and drivers.

Our results are consistent with findings of previous studies on driver retention and turnover, notably on the pivotal role the dispatcher plays in a driver's intention to quit or to stay (Richard, LeMay and Taylor, 1995; Keller and Ozment, 1999a, 1999b; Keller, 2002; Min and Lambert, 2002; Morrow et al., 2005; Paillé, Fournier and Lamontagne, 2011). This role is widely acknowledged by industry stakeholders, who overwhelmingly agree on its importance. More broadly, as dispatchers are viewed as immediate supervisors, as well as the primary representative of the carrier (Stinglhamber and Vandenberghe, 2003; Vandenberghe, 2004), the quality of their relationship with their drivers can be critical to the trust the latter builds with their employer (Rhoades and Eisenberger, 2002), as well as to job satisfaction (Griffeth and Hom, 2001; Price, 2001).

Moreover, our results also bring to light new aspects of the dispatcher-driver relationship. Firstly, the pressure to provide quality customer service appears to be a mediating variable in interactions between dispatchers and drivers. While the importance of the dispatcher in this relationship is universally recognized, the nature of "just-in-time" operations in the industry means that multiple work priorities will inevitably impact the workloads of drivers as well as dispatchers, and consequently affect their interpersonal relationships. In dealing with many unforeseeable situations, both can experience stress, frustration and see their manoeuvring room greatly reduced. In such a high-volume work environment, operational demands often supersede interpersonal ones, resulting in increased strain. Indeed, in stressful and demanding situations, players typically focus on work concerns and eschew personal ones, which are often perceived to be of secondary importance in the workplace (Cohen, 1980). Nevertheless, these concerns-operational and relational-are inextricably linked in both productivity and the retention of a skilled workforce. Maintaining good relationships showed positive effects on the capacity to deal with unforeseen events in operations and on mutual trust at work.

While previous studies have examined the dispatcher-driver relationship primarily from the perspective of the dispatcher's role in driver retention, our study 
more clearly establishes a more bi-directional, "win-win" relationship, gradually built through day-to-day interactions. This may be more pronounced given that drivers typically do not directly report to dispatchers. However, the function of the dispatcher's job requires a degree of operational supervision, albeit without any of the authority this entails. This structure therefore necessitates interdependence between dispatchers and drivers in both their daily work and interactions, where both players have a role and a responsibility to play. Maintaining a successful, interdependent relationship is thus a favourable condition for all players, where collaboration, listening and mutual respect are key to efficient and fulfilling work. Previous studies have also focused on the importance of good communication in dispatchers' interactions with their drivers. Our results demonstrate that the bi-directional nature of their relationship is not strictly limited to communication, but can extend across all other areas of interaction as well.

On a more practical level, these results could be seeds for innovative solutions. Indeed, the study's scope could be expanded beyond the role of the dispatcher in driver retention to explore promising courses of action that encompass the gamut of dispatcher-driver interactions: First, that hiring criteria include demonstrating interpersonal skills in high-stress situations (Jamal, 1990). Second, that work conditions (Suzuki, Crum and Pautsch, 2009) become an opportunity to reorganize dispatchers' and drivers' workloads so as to fine-tune interpersonal relationships. Lastly, as the results reveal both the importance of these relationships in the workplace and the challenges that multiple work priorities present, training for both dispatchers and drivers would benefit from fully considering these concerns. When both players are made aware of the value of their relationship, it leads to a better understanding of interpersonal dynamics in a high-pressure work environment.

In conclusion, our study provides a novel theoretical and methodological approach to an oft-studied issue: To better understand the dispatcher-driver relationship, we focused on day-to-day work experience using a reference model based on an analysis of activity (Guérin et al., 2006). The merit of this model is that it places situations of action (and interaction) at the centre of the analysis, in a context where inherent work-related and organizational pressures-as well as individual resources-are transformed and shape interactions. This approach provided a new understanding of the dynamic environment influencing the relationships between players in addressing issues of high turnover in the trucking industry. Such a model called for a qualitative approach to define the environment and isolate its key characteristics. Another innovative aspect of our approach was the use of a cross-perspective on the varied views of the different stakeholders to better capture the complexity of the issue. Moreover, the use of cross-self-evaluation (Clot, 2008) between drivers and dispatchers enabled us to 
broaden the scope of our study and better identify elements of the discourse and the respective rationales on the issue of qualified driver turnover.

The authors wish to note certain limitations of the present study which may nuance the results. We would like to clarify, however, that these limitations in no way compromise the validity of the study itself, nor its theoretical and practical results. First, the sampling technique used, purposive sampling, may be the cause of some selection bias. While only individuals and organizations concerned with this issue were selected for our study, a rigorous selection process-carried out in partnership with concerned organizations-ensured the representativeness and comprehensiveness of the views documented. Nevertheless, the findings of our study are comparable to previous studies (Richard, LeMay and Taylor, 1995; Shaw et al., 1998; Morrow et al., 2005) and given that representation of the various socio-demographic and professional indicators was obtained, any selection bias - if present-seems to have had little impact on the results. Second, the small number of respondents may also be a limitation. Third and finally, while an acknowledged limitation in qualitative research, the use of theoretical saturation as a tool allowed us to determine the exhaustiveness as well as the quality of the data collected (Kvale, 1996).

\section{References}

Ajzen, Icek and Martin Fishbein. 1980. Understanding Attitudes and Predicting Social Behavior. Englewoods Cliffs, New Jersey: Prentice-Hall.

Beilock, Richard and Russell B. Capelle. 1990. "Occupational Loyalties among Truck Drivers." Transportation Journal, 29 (3), 20-28.

Breslin, F. Curtis and Peter Smith. 2006. "Trial by Fire: A Multivariate Examination of the Relation between Job Tenure and Work Injuries." Occupational and Environmental Medicine, 63, 27-32.

Camo-route. 2005. Analyse d'enquêtes portant sur la main-d'oeuvre de l'industrie. Québec: Camo-route.

Clot, Yves. 2008. Travail et pouvoir d'agir. Paris: Presses Universitaires de France.

Cohen, Sheldon. 1980. "After Effects of Stress on Human Performance and Social Behavior: A Review of Research and Theory." Psychological Bulletin, 88 (1), 82-108.

Corsi, Thomas M. and Philip Fanara Jr. 1988. "Driver Management Policies and Motor Carrier Safety." Logistics and Transportation Review, 24 (2), 153-163.

DeConinck, James B. and Duane Bachmann. 2005. "An Analysis of Turnover among Retail Buyers." Journal of Business Research, 58 (7), 874-882.

De Croon, Einar M., Judith K. Sluiter, Roland W. B. Blonk, Jake P. J. Broersen and Monique H. W. Frings-Dresen. 2004. "Stressful Work, Psychological Job Strain, and Turnover: A 2-Year Prospective Cohort Study of Truck Drivers." Journal of Applied Psychology, 89 (3), 442-454.

De Montmollin, Maurice. 1986. L'intelligence de la tâche: éléments d'ergonomie cognitive. Berne: Peter Lang. 
Denzin, Norman K. and Yvonna S. Lincoln. 2005. The Sage Handbook of Qualitative Research. Thousand Oaks, CA: Sage Publications.

Dewey, John. 1963. Experience and Education. New York: Collier Books.

Eisenberger, Robert, Florence Stinglhamber, Christian Vandenberghe, Ivan L. Sucharski and Linda Rhoades. 2002. "Perceived Supervisor Support: Contribution to Perceived Organizational Support and Employee Retention." Journal of Applied Psychology, 87 (3), 565-573.

Ezzy, Douglas. 2003. Qualitative Analysis: Practice and Innovation. London: Routledge.

Foucher, Roland and Alain Gosselin. 2004. "Mettre en place une gestion de la relève: comment procéder, quelles pratiques adopter?" Gestion, 29 (3), 38-49.

Fournier, Pierre-Sébastien. 2003. L'aménagement de situations d'action sur le cours de vie professionnelle du camionneur: un apport à la démarche de conception d'une formation initiale en lien avec l'activité de travail. Québec: Université Laval.

Gouvernement du Québec. 1999. Le transport des marchandises au Québec: problématique et enjeux. Québec: Ministère des transports.

Griffeth, Rodger W. and Peter W. Hom. 2001. Retaining Valued Employees. Thousand Oaks, CA: Sage Publications.

Griffeth, Rodger W., Peter W. Hom and Stefan Gaertner. 2000. "A Meta-analysis of Antecedents and Correlates of Employee Turnover: Update, Moderator Tests and Research Implications for the Next Millennium." Journal of Management, 26 (3), 463-488.

Guérin, François, Antoine Laville, François Daniellou, Jacques Duraffourg and Alain Kerguelen. 2006. Comprendre le travail pour le transformer: la pratique de l'ergonomie. Lyon, France: ANACT.

Hirschman, Albert. 1970. Exit, Voice and Loyalty. Cambridge, MA: Harvard University Press.

Hom, Peter W. and Rodger W. Griffeth. 1995. Employee Turnover. Cincinnati, OH: South-Western.

Houkes, Inge, Peter P. M. Janssen, Jan de Jonge and Arnold B. Bakker. 2003. "Specific Determinants of Intrinsic Work Motivation, Emotional Exhaustion and Turnover Intention: A Multisample Longitudinal Study." Journal of Occupational and Organizational Psychology, 76 (4), 427-450.

Jamal, Muhammad. 1990. "Relationship of Job Stress and Type-A Behavior to Employees' Job Satisfaction, Organizational Commitment, Psychosomatic Health Problems, and Turnover Motivation." Human Relations, 43 (8), 727-738.

Keller, Scott B. 2002. "Driver Relationships with Customers and Driver Turnover: Key Mediating Variables Affecting Driver Performance in the Field." Journal of Business Logistics, 23 (1), 39-64.

Keller, Scott B. and John Ozment. 1999a. "Exploring Dispatcher Characteristics and their Effect on Driver Retention." Transportation Journal, 39 (1), 20-33.

Keller, Scott B. and John Ozment. 1999b. "Managing Driver Retention: Effects of the Dispatcher." Journal of Business Logistics, 20 (2), 97-120.

Kvale, Steinar 1996. Interviews: An Introduction to Qualitative Research Interviewing. Thousand Oaks, CA: Sage Publications.

Lamonde, Fernande and Sylvie Montreuil. 1995. "Le travail humain, I'ergonomie et les relations industrielles." Relations industrielles / Industrial Relations, 50 (4), 695-718. 
Maertz, Carl P. 2004. "Five Antecedents Neglected in Employee Turnover Models: Identifying Theoretical Linkages to Turnover for Personality, Culture, Organizational Performance, Occupational Attachment and Location Attachment." Innovative Theory and Empirical Research on Employee Turnover. R. Griffeth and P. Hom, eds. Greenwich, CT: Information Age Publishers.

Meyer, John P., Natalie J. Allen and Catherine A. Smith. 1993. "Commitment to Organizations and Occupations: Extension and Test of a Three-Component Conceptualization." Journal of Applied Psychology, 78 (4), 538-551.

Meyer, John P. and Lynne Herscovitch. 2001. "Commitment in the Workplace: Toward a General Model." Human Resource Management Review, 11 (3), 299-326.

Min, Hokey and Thomas Lambert. 2002. "Truck Driver Shortage Revisited." Transportation Journal, 42 (2), 5-16.

Mobley, William H. 1982. Employee Turnover: Causes, Consequences and Control. London: Addison-Wesley.

Morrow, Paula C., Yoshinori Suzuki, R. Michael Crum, Robert Ruben and Gregory Pautsch. 2005. "The Role of Leader-Member Exchange in High Turnover Work Environments." Journal of Managerial Psychology, 20 (8), 681-694.

Mucchielli, Alex. 1991. Les méthodes qualitatives. Paris: Presses Universitaires de France.

Natanson, Maurice. 1962. "Introduction." Collected Papers I: The Problem of Social Reality. A. Schutz, ed. The Hague: Martinus Nijhoff, xxv-xlvii.

Paillé, Pascal, Pierre-Sébastien Fournier and Sophie Lamontagne. 2011. "Relationships between Commitments to the Organization, the Superior and the Colleagues, and the Intention to Leave among Truckers." International Journal of Organizational Analysis, 19 (2), 92-108.

Price, James L. 2001. "Reflection on the Determinants of Voluntary Turnover." International Journal of Manpower, 22 (7), 600-624.

Price-Waterhouse. 1990. L'industrie canadienne du camionnage, défis des ressources humaines et possibilités de l'emploi. Ottawa: Emploi et Immigration Canada.

Rhoades, Linda and Robert Eisenberger. 2002. "Perceived Organizational Support: A Review of Literature." Journal of Applied Psychology, 87 (4), 698-714.

Richard, Michael D., Stephen A. LeMay and G. Stephen Taylor. 1995. "A Factor-analytic Logit Approach to Truck Driver Turnover." Journal of Business Logistics, 16 (1), 281-298.

Shaw, Jason D., John E. Delery, Douglas G. Jenkins and Nina Gupta. 1998. "An OrganizationLevel Analysis of Voluntary and Involuntary Turnover." Academy of Management Journal, 41 (5), 511-525.

Smith, Patricia C., Lorne M. Kendall and Charles L. Hulin. 1969. The Measurement of Satisfaction in Work and Retirement: A Strategy for the Study of Attitudes. Chicago: Rand McNally.

Staplin, Loren and Kenneth W. Gish. 2005. "Job Change Rate as a Crash Predictor for Interstate Truck Drivers." Accident Analysis and Prevention, 37 (6), 1035-1039.

Stephenson, Frederick J. and Richard J. Fox. 1996. "Driver Retention Solutions: Strategies for Hire Truckload (TL) Employee Drivers." Transportation Journal, 35 (4), 12-25.

Stinglhamber, Florence and Christian Vandenberghe. 2003. "Organizations and Supervisors as Sources of Support and Targets of Commitment: A Longitudinal Study." Journal of Organizational Behavior, 24 (3), 251-270. 
Suzuki, Yoshinori, Michael R. Crum and Gregory R. Pautsch. 2009. "Predicting Truck Driver Turnover." Transportation Research, Part E 45, 538-550.

Tett, Robert P. and John P. Meyer. 1993. "Job Satisfaction, Organizational Commitment, Turnover Intention and Turnover: Path Analysis Based on Meta-analytic Findings." Personnel Psychology, 46 (2), 259-293.

Vandenberg, Robert J. and Jodi B. Nelson. 1999. "Disaggregating the Motives Underlying Turnover Intentions: When Do Intentions Predict Turnover Behavior?" Human Relations, 52 (10), 1313-1336.

Vandenberghe, Christian. 2004. "Conserver ses employés productifs: nature du problème et stratégies d'intervention." Gestion, 29 (3), 64-72.

Varela, Francisco J. 1989. Autonomie et connaissance: essai sur le vivant. Paris: Seuil.

Vygotski, Lev. 1997. Pensée et langage. Paris: La Dispute.

Yin, Robert K. 1994. Case Study Research: Design and Methods. Thousand Oaks, CA: Sage Publications.

\section{SUMMARY}

\section{Interactions between Dispatchers and Truck Drivers in a High Turnover Context}

The North American trucking industry has been facing chronic issues related to the retention of a skilled workforce since the end of the 1980s. These issues have both direct economic and social impact; for example, high driver turnover has been linked to higher accident rates. Research has revealed a clear link between the dispatcher's role and driver turnover, yet little is known about the interactions of this relationship in day-to-day work experience. The aim of the present article, therefore, is to document the dynamic environment shaping interactions between dispatchers and truck drivers in addressing issues related to high turnover. In order to capture the daily interactions of these players, a qualitative approach was used, based on 17 individual interviews and three group discussions with dispatchers, truck drivers and labour and management representatives from 11 different Quebecbased organizations. The results reveal four key characteristics influencing the day-to-day dynamics of trucking operations: 1) the importance of dispatcher-driver interaction in efficient and quality work operations; 2) the precedence of customer satisfaction in these interactions; 3) the interdependent nature of the dispatcherdriver relationship; and lastly, 4) the role of listening and mutual respect. More specifically, the results suggest that dispatcher-driver interactions tend to occur in a high-pressure environment where work demands often necessitate prioritizing operational concerns over interpersonal ones. They also demonstrate that a bidirectional, "win-win" relationship based on constructive interactions, listening and mutual respect are essential conditions in achieving both work efficiency and job satisfaction. These results appear to confirm the findings of several previous studies and shed new light on understanding the relationship between these players.

KEYWORDS: dispatchers, truck drivers, retention, turnover 


\section{RÉSUMÉ}

\section{Les relations entre les répartiteurs et les camionneurs en contexte de roulement élevé de main-d'œuvre}

Les problèmes de rétention de main-d'œuvre qualifiée se dessinent depuis les années 80 dans l'industrie du transport routier des marchandises en Amérique du Nord. Ces problèmes entraîneraient des conséquences économiques et sociales importantes. Par exemple, une augmentation du taux de roulement serait associée à une augmentation des accidents. La littérature scientifique a clairement établi un lien entre le rôle du répartiteur et le roulement des camionneurs. Si ce lien est bien connu, on en sait peu sur la dynamique de cette relation dans la réalité quotidienne du travail. L'objectif de cet article consiste à documenter le contexte dynamique qui structure la relation entre les répartiteurs et les camionneurs pour faire face aux problèmes de roulement de main-d'œuvre. Une démarche qualitative visant à documenter la réalité quotidienne des acteurs a été utilisée. Elle repose sur 17 entrevues individuelles et trois entretiens collectifs réalisés auprès de représentants patronaux, de répartiteurs, de représentants syndicaux et de camionneurs œuvrant dans 11 organisations distinctes. Les résultats présentent des caractéristiques de la dynamique du travail au quotidien : l'importance de la relation dans l'efficacité et la qualité des opérations, la prédominance de la satisfaction du client dans la relation, la relation d'interdépendance entre le répartiteur et le camionneur et, finalement, l'écoute et le respect dans les activités de transport. De façon plus spécifique, l'étude montre un contexte d'interaction caractérisé par de fortes contraintes de travail où la pression productive amène souvent les acteurs à prioriser les préoccupations opérationnelles aux dépens des aspects relationnels. De plus, elle montre une relation de donnant donnant entre les acteurs où les bonnes relations, le respect et l'écoute constituent des conditions importantes pour la réalisation efficace et satisfaisante du travail. Ces résultats confirment plusieurs constats d'études précédentes et apportent de nouveaux éclairages dans la compréhension de la relation entre ces acteurs.

MOTS-CLÉS : camionneurs, répartiteurs, rétention, main-d'œuvre

\section{RESUMEN}

\section{Las relaciones entre los repartidores y los camioneros en contexto de rotación elevada de mano de obra}

Los problemas de retención de mano de obra calificada se presentan desde los años 80 en la industria del transporte terrestre de mercancías en América del Norte. Esos problemas comportan consecuencias económicas y sociales importantes. Por ejemplo, una aumentación de la tasa de rotación estaría asociada a una aumentación de los accidentes. La literatura científica ha establecido claramente un vínculo entre el rol del repartidor y los camioneros para hacer frente a los problemas de rotación de mano de obra. Para documentar la realidad cotidiana de los actores se 
utilizó un procedimiento cualitativo que comprende 17 entrevistas individuales y tres entrevistas colectivas realizadas con representantes patronales, repartidores, representantes sindicales y camioneros provenientes de 11 organizaciones diferentes. Los resultados presentan características de la dinámica del trabajo cotidiano: la importancia de la relación para la eficacia y la calidad de las operaciones, la predominancia de la satisfacción del cliente en la relación, la relación de interdependencia entre el repartidor y el camionero y, finalmente, la escucha y el respecto en las actividades de transporte. De manera más específica, el estudio muestra un contexto caracterizado por fuertes coerciones del trabajo donde la presión productiva lleva a los actores a priorizar las preocupaciones operacionales en detrimento de los aspectos relacionales. Además, se muestra una relación de "toma y daca" entre los actores en la cual las buenas relaciones, el respeto y la escucha constituyen condiciones importantes para la realización eficaz y satisfactoria del trabajo. Estos resultados confirman varias constataciones de estudios precedentes y aportan nuevos esclarecimientos en la comprensión de la relación entre esos actores.

PALABRAS CLAVES: camioneros, repartidores, retención, mano de obra 